JPPIPA, Vol. 3 No. 22018
Jurnal Penelitian Pendidikan IPA
http://journal.unesa.ac.id/index.php/jppipa

\title{
PEMBELAJARAN FISIKA DASAR MENGGUNAKAN E-LEARNING UNTUK MENINGKATKAN LITERASI SAINS MAHASISWA
}

Oleh:

Moh. Budiyanto ${ }^{1}$, Elok Sudibyo ${ }^{2)}$, Ahmad Qosyim ${ }^{3}$

1,2,3 Jurusan IPA, Fakultas Matematika dan Ilmu Pengetahuan Alam, Universitas Negeri Surabaya, Surabaya 60231, Indonesia.

\begin{abstract}
Abstrak
Penelitian ini untuk meningkatkan literasi sains mahasiswa dengan menggunakan e-learning pada pembelajaran fisika dasar. E-learning merupakan solusi dalam menawarkan berbagai kemungkinan jaringan sosial sehingga dengan cara tersebut pengajar dapat menyimpan berbagai catatan interaksi peserta didik dalam pembelajaran. Bentuk perkuliahan dengan menggunakan e-learning sebagai alat bantu untuk memahami materi merupakan hal yang baik. Bentuk video dalam e-leraning merupakan bentuk video yang berupa fakta-fakta fenomena terkait dengan materi perkuliahan fisika dasar pada konsep suhu dan kalor sehingga memberikan efek dalam literasi sains mahasiswa. Adapun yang fokus literasi sains dalam penelitian ini adalah pengetahuan mahasiswa, kemampuan membuat kesimpulan dan pengambilan keputusan. Penelitian ini untuk mengetahui gambaran umum tentang implementasi pembelajaran elearning yang dilihat dari perencanaan, pelaksanaan dan evaluasi pembelajaran elearning. Fokus literasi sains mahasiswa materi perkuliahan fisika dasar pada konsep suhu dan kalor yakni pengetahuan mahasiswa, kemampuan membuat kesimpulan dan pengambilan keputusan. Desain penelitian yang digunakan untuk uji coba produk adalah One Group Pretest-Posttest Design. Hasil penelitian menunjukkan adanya peningkatan kemampuan literasi sains yang signifikan khususnya komponen pengetahuan, membuat kesimpulan dan pengambilan keputusan. Hasil analisis N-Gain menunjukkan kemampuan literasi sains mahasiswa dalam pembelajaran fisika kemampuan pengetahuan, kesimpulan, dan pengambilan keputusan pada materi suhu dan kalor menunjukkan sebagian besar kategori sedang.
\end{abstract}

Kata Kunci: e-learning, literasi sains, pembelajaran fisika dasar

\begin{abstract}
This research is to improve student literacy by using e-learning in basic physics learning. E-learning is a solution in relation to social networks so that in this way the teacher can store various records of student interactions in learning. The form of lectures using e-learning as a tool to consider material is a good thing. The form of video in e-learning is a form of video consisting of facts related to basic physics lecture material on the concepts of temperature and heat so as to provide an effect on student scientific literacy. Related to the focus of literacy in this study are student knowledge, the ability to make conclusions and decision making. This research is to study the general description of the implementation of elearning learning which is seen from the planning, implementation and evaluation of elearning learning. The focus of scientific literacy is students on basic physics material on the concepts of temperature and heat of student knowledge, the ability to make conclusions and decision making. The research design used to test the product is the Pretest-Posttest One Group Design. The results of the study indicate that there is an increase in literacy skills that are significantly specific to the knowledge component, make conclusions and make decisions. The results of $N$-Gain's analysis show students' literacy skills in physics learning the ability of knowledge, conclusions, and decision making on temperature and heat materials showed that most categories were moderate.
\end{abstract}

Keywords: e-learning, scientific literacy, basic physics learning

(C) 2018 Universitas Negeri Surabaya

$\begin{array}{ll}{ }^{2} \text { Alamat Korespondensi: } & \text { p-ISSN: 2527-7537 } \\ \text { Jurusan IPA, FMIPA, Unesa, } & \text { e-ISSN: 2549-2209 } \\ \text { Email: mohammadbudiyanto@ unesa.ac.id } & \end{array}$ 


\section{PENDAHULUAN}

Penyelenggaraan perkuliahan berpegang pada prinsip efisiensi dan efektivitas yakni pemanfaatan waktu yang terbatas secara optimal untuk mencapai tujuan. Karena itu, tiap metode perkuliahan yang dipilih, diorientasikan pada tujuan prinsip umum yang digunakan dalam proses belajar mengajar dengan cara belajar konstruktivis. Proses belajar mengajar dituntut adanya interaksi antara dosen dan mahasiswa. Interaksi dalam proses belajar mengajar antara dosen dengan mahasiswa dimana dosen sebagai fasilitator dengan mahasiswa dituntut untuk lebih aktif dalam pembelajaran.

Fisika dasar merupakan salah satu mata kuliah di Program Studi Pendidikan IPA FMIPA Universitas Negeri Surabaya yang ditempuh mahasiswa semester satu. Mata kuliah ini merupakan mata kuliah wajib, yang harus ditempuh oleh seluruh mahasiswa Prodi P endidikan IPA Fakultas MIPA. Mata kuliah ini tergolong mata kuliah u mum, sehingga materi perkuliahan yang disajikan adalah berbagai metode dan teknik sebagai alat bantu dalam mempelajari berbagai materi perkuliahan Prodi P endidikan IPA. Setelah mengikuti perkuliahan ini, mahasiswa diharapkan memiliki wawasan pengetahuan dan pemahaman yang baik terhadap berbagai metode dan teknik fisika dasar, serta dapat menggunakannya dalam berbagai proses pemecahan masalah, baik yang terkait persoalan fisika itu sendiri maupun yang terkait dengan persoalan Sains. Dalam perkuliahan ini dibahas materi-materi mekanika, zat dan energi, serta suhu dan kalor. Isi mata kuliah disajikan secara interaktif melalui proses ceramah, diskusi, dan latihan. Penjelasan materi perkuliahan dilakukan melalui pendekatan pemecahan masalah terkait dengan persoalan-persoalan Sains yang relevan dan untuk pembelajaran penguasaan pemahaman materi bisa dibantu dengan media internet yang dikenal istilah $E$ learning.

E-learning merupakan solusi dalam menawarkan berbagai kemungkinan jaringan sosial sehingga dengan cara tersebut pengajar dapat menyimpan berbagai catatan interaksi peserta didik dalam pembelajaran kolaborasi, seperti halnya kelas konvensional aktivitas yang bisa dilakukan melalui e-learning adalah forum, chating, modul, penugasan, dan kuis (evaluasi). Melalui media tersebut berbagai layanan multimedia dapat ditransfer dengan mudah, seperti audio, video, grafik yang memiliki resolusi tinggi sehingga proses berpikir dapat menuju dalam pemikiran yang kongkret. Berdasarkan hasil penelitian yang telah dilakukan oleh Widodo dan
Rosdiana (2015) penerapan e-learning pada mata kuliah gelombang optik dapat meningkatkan pemahaman konsep mahasiswa. Hasil penelitian ini masih ada kekurangan saat mahasiswa membuat grafik, sehingga perlu ditingkatkan kemampuan mahasiswa dalam membuat grafik dalam mengaplikasikan konsep dalam kehidupan sehari- hari. Hal ini merupakan tantangan yang besar untuk materi perkuliahan lainnya, sehingga semua proses perkuliahan perlu diterapkan pembelajaran dengan menggunakan media yang mampu melibatkan berpikir kritis.

Dalam E-learning segala informasi dapat termuat, sehingga masing-masing individu harus memiliki kemampuan untuk menyaring dan kritis terhadap informasi yang ada. Menurut paradigma konstruktivisme Piaget, salah satu kecakapan yang penting dimiliki oleh mahasiswa adalah kecakapan dalam mengatur dan mengontrol proses berpikirnya, antara lain kecakapan berpikir kritis, yaitu keterampilan individu menggunakan strategi berpikir dalam menganalisis argumen dan memberikan interpretasi berdasarkan persepsi yang benar dan rasional, analitis asumsi, dan bias dari argumen serta interpretasi logis. Pola berpikir seperti ini termasuk ke dalam pola berpikir tingkat tinggi dan keterampilan literasi sains.

Literasi sains menurut PISA (Programme for International Student Assesment) oleh OECD (Organization for Economic Cooperation and Development) (2004:26), didefinisikan sebagai berikut "the capacity to use scientific knowledge, to identify questions and to draw evidence-based conclusions in order to understand and help make decisions about the natural world and the changes made to it through human activity". Hal ini menunjukkan bahwa literasi sains bersifat multidimensional dalam aspek pengukurannya yaitu konten sains, proses dan aplikasi sains. Hasil studi PISA pada tahun 2015 siswa dari Indonesia menunjukkan pencapaian level literasi sains ratarata level tiga. Pada target penelitian ini diharapkan mahasiswa dalam pembelajaran fisika dasar konsep suhu dan kalor bisa mencapai level enam.

Literasi sains penting dikuasai karena pemahaman IPA menawarkan pemenuhan personal dan kegembiraan untuk dibagikan kepada siapapun. Selain itu negara-negara dihadapkan kepada pertanyaan dalam kehidupan yang memerlukan informasi ilmiah dan cara berfikir ilmiah untuk mengambil keputusan dan kepentingan orang banyak yang perlu diinformasikan. Pemahaman dan kemampuan dalam IPA juga dapat meningkatkan kapasitas siswa untuk menjadi pekerja pemula yang siap menjadi masyarakat bisnis di masa depan. Negaranegara lain telah melakukan investasi yang 
besar untuk menciptakan motivasi bekerja yang "literate" secara ilmiah dan teknologi. Hal ini dilakukan untuk bertahan dipasar global sehingga setiap negara perlu memiliki warga negara yang memiliki kapabiliti yang sama (Layli, 2018)

Dari uraian diatas peneliti melakukan penelitian tentang pembelajaran fisika dasar menggunakan e-learning untuk meningkatkan literasi sains mahasiswa materi perkuliahan fisika dasar pada konsep suhu dan kalor. Fokus penelitian literasi sains ini pada materi perkuliahan fisika dasar konsep suhu dan kalor yakni pengetahuan mahasiswa, kemampuan membuat kesimpulan dan pengambilan keputusan. Adapun rumusan masalah pada penelitian ini adalah bagaimana meningkatkan keterampilan keterampilan literasi sains mahasiswa dalam pembelajaran Fisika dasar konsep suhu dan kalor dengan menggunakan e-learning?. Penelitian ini bertujuan untuk menerapkan e-learning pada pembelajaran fisika dasar dapat meningkatkan literasi sains mahasiswa.

\section{METODE}

Jenis penelitian ini merupakan penelitian terapan yaitu penerapan e-learning pada mata kuliah fisika dasar untuk meningkatkan keterampilan literasi sains mahasiswa. Metode penelitian yang digunakan dalam penelitian ini adalah penelitian deskriptif kualitatif. Penelitian deskriptif dimaksudkan untuk mengetahui gambaran umum tentang implementasi pembelajaran elearning yang dilihat dari perencanaan, pelaksanaan dan evaluasi pembelajaran elearning terhadap kemampuan berpikir kritis mahasiswa. Subjek dalam penelitian ini adalah mahasiswa yang mengambil mata kuliah fisika dasar pada semester satu tahun ajaran 2018/2019 Jurusan IPA FMIPA Unesa. Sasaran penelitian ini adalah mahasiswa Jurusan IPA yang mengambil mata kuliah Fisika Dasar.

Desain penelitian ini adalah One Group Pretest-Posttest Design dimana terdapat nilai pretest yaitu nilai yang diambil sebelum diberi perlakuan kemudian dibandingkan dengan keaadan sesudah diberi perlakuan (posttest).

Instrumen penelitian yang digunakan dalam penelitian ini adalah lembar yang berisi tentang butir-butir soal keterampilan literasi sains yang digunakan untuk mengukur hasil belajar mahasiswa dengan digunakannya media $e$ learning dalam proses pembelajaran fisika dasar.

Teknik pengumpulan data pada penelitian ini menggunakan metode tes. Tes diguanakan untuk mengukur hasil belajar dalam segi konsep pengetahuan mahasiswa. Tes yang digunakan ada dua tes yakni pre-test yang dilakukan di awal pembelajaran kemudian post-test yang dilakukan di akhir pembelajaran untuk mengetahui keterampilan literasi sains mahasiswa.

Data kemampuan literasi sains mahasiswa digunakan untuk mengukur hasil belajar siswa selama proses pembelajaran. Data didapat berdasarkan nilai pre-test dan post-test yang kemudian dianalisis untuk melihat peningkatan keterampilan literasi sains mahasiswa. Kemudian dilakukan perhitungan untuk mengetahui peningkatan nilai pre-test dengan nilai post-test maka dilakukan analisis Gain dengan menggunakan persamaan dibawah ini :

$$
<g>=\frac{\text { posttest }- \text { pretest }}{100-\text { pretest }}
$$

Kemudian, setelah dilakukan perhitungan dengan menggunakan persamaan tersebut, skor yang didapat oleh mahasiswa dikonversi dengan menyesuaikan pada kriteria berikut :

Tabel 1. Konversi skor siswa dalam analisis N-Gain

\begin{tabular}{|c|c|}
\hline Skor & Kriteria \\
\hline $0,0<(<\mathrm{g}>) \leq 0,3$ & Rendah \\
\hline $0,3<(<\mathrm{g}>) \leq 0,7$ & Sedang \\
\hline $0,7<(<\mathrm{g}>) \leq 1,0$ & Tinggi \\
\hline
\end{tabular}

\section{HASIL DAN PEMBAHASAN}

Hasil penilaian literasi sains mahasiswa digunakan untuk mengukur hasil belajar mahasiswa selama proses pembelajaran menggunaka e-learning. Data didapat berdasarkan nilai pre-test dan post-test yang kemudian dianalisis untuk melihat peningkatan keterampilan literasi sains mahasiswa.

hasil penilaian literasi sains mahasiswa pada pembelajaran fisika dasar khususnya materi suhu dan kalor melalui pembelajaran e-learning mengalami peningkatan yang signifikan antara pretes dan postes. Dari tiga komponen literasi sains pengetahuan, kesimpulan dan pengambilan keputusan pada pembelajaran fisika dasar materi suhu dan kalor rata-rata baik. Penilaian awal literasi sains mahasiswa sebelum pembelajaran elearning pada pembelajaran fisika dasar materi suhu dan kalor diperoleh nilai rata-rata pengetahuan 51,03; kesimpulan 48,10; dan pengambilan keputusan 46,90. Kemudian mahasiswa melakukan pembelajaran melalui 
pembelajaran e-learning fisika dasar melalui aplikasi di Siakad Universitas Negeri Surabaya dan dilakukan evaluassi akhir dengan perolehan nilai rata-rata pengetahuan 81,28 ; kesimpulan 76,21 ; dan pengambilan keputusan 73,28. Hasil analisis $\mathrm{N}$-Gain diperoleh nilai rata-rata pengetahuan 0,62 ; kesimpulan 0,54 ; dan pengambilan keputusan 0,50 . Adapun jumlah mahasiswa dan prosentase analisis N-Gain dapat dilihat pada tabel 4.2 berikut.

Tabel 2. Rekapitulasi data komponen lietrasi sains dan prosentase dalam analisis N-Gain

\begin{tabular}{|c|c|c|c|c|c|c|c|}
\hline Skor & $\mathbf{P}$ & $\mathbf{K}$ & $\mathbf{P K}$ & $\mathbf{\% P}$ & $\mathbf{\% K}$ & $\mathbf{\% P K}$ & Kriteria \\
\hline $0,0<(<\mathrm{g}>) \leq 0,3$ & 0 & 0 & 0 & $0 \%$ & $0 \%$ & $0 \%$ & Rendah \\
\hline $0,3<(<\mathrm{g}>) \leq 0,7$ & 26 & 28 & 25 & $89,3 \%$ & $96,6 \%$ & $86,2 \%$ & Sedang \\
\hline $0,7<(<\mathrm{g}>) \leq 1,0$ & 3 & 1 & 4 & $10,7 \%$ & $3,4 \%$ & 13,8 & Tinggi \\
\hline
\end{tabular}

Berdasarkan hasil kemampuan literasi sains mahasiswa melalui pembelajaran e-learning pada pembelajaran fisika dasar materi suhu dan kalor menunjukkan kemampaun pengetahuan rata-rata tinggi, sedangkan kemampuan mahasiswa dalam membuat kesimpulan dan pengambilan keputusan masih rendah. Hal ini juga ditunjukkan adanya peningkatan kemampuan literasi pengetahuan yang signifikan dibandingkan membuat kesimpulan dan pengambilan keputusan. Analisis $\mathrm{N}$-Gian kemampuan literasi sains mahasiswa dalam pembelajaran fisika kemampuan pengetahuan, kesimpulan, dan pengambilan keputusan pada materi suhu dan kalor menunjukkan sebagian besar kategori sedang. Prosentase kemampuan pengetahuan kategori sedang $89,3 \%$ dan kategori tinggi $10,7 \%$. Prosentase kemampuan membuat kesimpulan kategori sedang 96,6\% dan kategori tinggi 3,4\%. Prosentase kemampuan pengambilan keputusan kategori sedang 86,2\% dan kategori tinggi 13,8\%. Hasil tersebut menunjukkan adanya peningkatan kemampuan literasi sains mahasiswa pada pembelajaran fisika melaui e-learning yang signifikan dengan kategori sedang.

\section{PENUTUP}

Berdasarkan analisis data dan pembahasan penelitian menunjukkan adanya peningkatan kemampuan literasi sains yang signifikan khususnya komponen pengetahuan, membuat kesimpulan dan pengambilan keputusan. Hasil analisis N-Gian kemampuan literasi sains mahasiswa dalam pembelajaran fisika kemampuan pengetahuan, kesimpulan, dan pengambilan keputusan pada materi suhu dan kalor menunjukkan sebagian besar kategori sedang.

Penelitian penggunaan literasi sains melalui pembelajaran e-learning bisa dilakukan untuk materi fisika dasar yang lain dengan adanya penekanan kemampuan membuat kesimpulan dan pengambilan keputusan. Penelitian penggunaan literasi sains melalui pembelajaran e-learning bisa dilakukan untuk mata kulaih yang lain.

\section{DAFTAR PUSTAKA}

Clark, R. C., \& Mayer, R. E. (2016). E-learning and the science of instruction: Proven guidelines for consumers and designers of multimedia learning: John Wiley \& Sons.

Kementerian Pendidikan dan Kebudayaan (2016) Gerakan Literasi Sekolah Direktorat Pembinaan Sekolah Menengah Pertama

Laily Rosdiana, Tutut Nurita , Wahyu Budi Sabtiawan. 2018. Pengembangan LKM untuk meningkatkan literasi sains calon guru ipa. Jurnal Penelitian Pendidikan IPA, Vol. 3, No. 1, 8-14

Putra, P. D. A., \& Sudarti, S. (2015). Real life video evaluation dengan sistem elearning untuk meningkatkan keterampilan berpikir kritis mahasiswa. Jurnal Kependidikan: Penelitian Inovasi Pembelajaran, 45(1), 76-89.

Saadé, R. G., Morin, D., \& Thomas, J. D. E. (2012). Critical thinking in E-learning environments. Computers in Human Behavior, 28(5), 1608-1617. doi:10.1016/j.chb.2012.03.025

Songkram, N. (2015). E-learning system in virtual learning environment to develop creative thinking for learners in higher education. Procedia-Social and Behavioral Sciences, 174, 674-679.

Sriarunrasmee, J., Suwannatthachote, P., \& Dachakupt, P. (2015). Virtual Field Trips with Inquiry learning and Critical Thinking Process: A Learning Model to Enhance Students' Science Learning 
Outcomes. Procedia - Social and Behavioral Sciences, 197, 1721-1726. doi:10.1016/j.sbspro.2015.07.226

Welsh, E. T., Wanberg, C. R., Brown, K. G., \& Simmering, M. J. (2003). E-learning: emerging uses, empirical results and future directions. international Journal of Training and Development, 7(4), 245258.

Widodo, W \& Inzanah. 2014. Literasi Sains Mahasiswa Program Studi S1 Pendidikan IPA Universitas Negeri Surabaya. Prosiding yang dipublikasikan pada Seminar Nasional dengan tema "Peran Literasi Sains Untuk Menyiapkan Generasi Dalam Menghadapi Asean Comunity". 